\title{
Newcastlen taudin eteneminen, bioturvallisuus ja vaikutukset siipikarjanlihan tuotannossa
}

\author{
Heidi Rosengren ${ }^{1}$, Jaakko Heikkilä ${ }^{2}$, Kirsi-Maarit Siekkinen ${ }^{1}$ ja Niina Tammiranta ${ }^{1}$, \\ ${ }^{1}$ Riskinarviointiyksikkö, Evira, Mustialankatu 3,00790 Helsinki, etunimi.sukunimi@evira.fi \\ ${ }^{2}$ MTT Taloustutkimus, Luutnantintie 13,00410 Helsinki, etunimi.sukunimi@mtt.fi
}

\section{Tiivistelmä}

Lintuinfluenssan ohella paramyksovirus-1:n (PMV-1) aiheuttama Newcastlen tauti (ND) on siipikarjasektorilla yksi vakavimmista eläintaudeista, jolla on merkittäviä terveydellisiä seurauksia tartunnan saaneille linnuille. Tästä syystä taudin leviämistä vastustetaan maailmanlaajuisesti, ja se on kansainvälisen eläintautijärjestön (OIE) sekä Euroopan Unionin korkeimmin priorisoituja siipikarjatauteja. Riskistatuksestaan johtuen ND:1lä on esiintyessään myös muitakin kuin terveydellisiä vaikutuksia, jotka vaikuttavat siipikarjan tautitilanteen seurantaan ja riskinhallintaan sekä näistä johtuviin taloudellisiin seurauksiin. Tässä tutkimuksessa tarkastelimme epidemiologisten ja riskinhallinnan tapahtumasarjojen vaikutusten yhteyksiä ND:n taloudellisiin vaikutuksiin ja niiden kohdentumisen Suomessa.

ND -taudinpurkauksen kulku on tapahtumasarja, johon vaikuttaa sekä PMV-1 että sen biologiset ominaisuudet, tartunnan leviämismekanismit ja lintujen immuunivaste, mutta myös ihmisten toiminta (tuotantotavat ja -rakenne, kauppa, riskinhallintapolitiikka). Bioturvallisuutta ja ND:n esiintymisen seurantaa pidetään yllä sekä tautivapaana että taudinpurkauksen aikana, ja siksi myös sen vaikutuksia on tarkasteltava molempina ajanjaksoina. Ihmistoiminnan seurauksena bioturvallisuus voi joko parantua tai huonontua ja vaikuttaa siten epidemiologiseen tapahtumasarjaan: esimerkiksi siipikarjasektorin tuotannolliset ratkaisut voivat vaikuttaa tartunnan leviämisen riskiin.

Taudin leviämisen estämiseksi sekä tartunnan hävittämiseksi tehdyt toimenpiteet tuovat osalle toimijoista kustannuksia, jotka heijastuvat toisille toimijoille kustannuksina tai hyötyinä. ND:n kustannusvaikutukset ulottuvat siipikarjasektorin lisäksi myös sektorin ulkopuolisiin toimijoihin, esimerkiksi tuotantopanosten tuottajiin sekä täysin sivullisiin toimijoihin kuten elämyselinkeinoihin ja harrastajiin. Terveydelliset vaikutukset voivat ulottua siipikarjan lisäksi myös luonnonvaraisiin lintuihin, jotka saman eläintyypin vapaina edustajina elävät tuotantoeläinten läheisyydessä.

Bioturvallisuus on ns. julkishyödyke, jota markkinat eivät tuota riittävästi. Tästä johtuva valtion mukanaolo tuo esiin koko joukon valintoja: Miten turvallisuus tuotetaan? Mikä on sopiva määrä? Kuka sen maksaa? Miten sitä valvotaan? Riskinarviointiin liittyvälle tutkimukselle on tarvetta jo pelkästään kansainvälisten sitoumustemme takia, mutta myös kansallisista tehokkuusnäkökohdista tarkasteltuna. On myös merkkejä siitä, että vastuu bioturvallisuuden ylläpitämisestä on siirtymässä yhä enenevässä määrin viranomaisilta elinkeinolle ja tuottajille. Kustannusten ja hyötyjen jakautumisen kautta päästään pohtimaan, millaisia kannusteita eri toimijoilla on ylläpitää bioturvallisuutta ja toimia vastuullisesti koko yhteiskunnan kannalta. Jatkossa yhdistämällä tätä tietoa ND:n riskinarviointiin voidaan selvittää bioturvallisuuden ja taudinpurkauksen vaikutusten suuruus ja kohdistuminen, ja saada näin perusteet yhteiskunnan kannalta edullisimpien ND:n vastustustoimenpiteiden valinnalle.

\section{Asiasanat}

Siipikarjanlihan tuotanto, Newcastlen tauti, bioturvallisuus, riskinhallinta, tautivastustuskustannukset, vaikutusten kohdentuminen 


\section{Johdanto}

Eläinten tarttuvia tauteja vastustetaan, koska niillä voi olla epäedullisia vaikutuksia ihmisten tai eläinten terveydelle ja hyvinvoinnille ja sitä kautta eläintuotannon taloudelliselle tulokselle. Levitessään luonnonvaraisiin eläimiin taudilla voi olla myös ympäristöllisiä seurauksia. Yhteiskunnalliset (sosiaaliset, poliittiset ja kansantaloudelliset) vaikutukset riippuvat yhteiskunnan reaktioista tilanteeseen. Esimerkkejä eri tautiepidemioiden aiheuttamista kustannuksista on maailmalta useita. Esimerkiksi Taiwanin (1997) ja Iso-Britannian (2001) suu- ja sorkkatautiepidemiat sekä Hollannin klassinen sikarutto (1997-1998) maksoivat kaikki miljardeja dollareita. Kokonaissummat eivät yleensä ole keskenään vertailukelpoisia, eikä niistä myöskään ole juuri hyötyä tehtäessä yksittäisiä taudinhallintapäätöksiä. Niistä on kuitenkin nähtävissä mahdollisten vahinkojen suuruusluokka.

Euroopan Unionin (EU) eläinten terveyttä koskevan strategian arvioinnin raportissa (European Commission 2006) korostetaan mm. eläintautien ennaltaehkäisyn ja bioturvallisuuden olevan yhä tärkeämpi eläintauteihin käytetyn yhteisön rahoituksen kohdentamiselle. Raportissa korostetaan bioturvallisuuden vahvistamista tilatasolta aina globaalille tasolle asti. Taudinpurkausten hallinnan kustannukset ja vastuut tulisi raportin mukaan kohdistaa suhteessa eri toimijoiden aiheuttamaan riskiin. Taustapaperissaan eläintauteihin liittyvistä talouskysymyksistä OECD (2007) määritteli viisi teemaa, joihin liittyy erityisiä tutkimuksellisia haasteita. Näistä yksi on kustannusten ja hyötyjen jakautuminen.

Paramyksovirus-1 (PMV-1) on siipikarjalle Newcastlen tautia (ND) aiheuttava, populaatiossa herkästi leviävä virus. ND on linnuille vakava tauti, joka leviää lintujen välillä ja tilalta toiselle sekä suoraan tartuntaa kantavien elävien lintujen että epäsuorasti ihmisten ja saastuneiden laitteiden ja välineiden välityksellä. Uudessa Seelannissa tehdyssä tutkimuksessa (McKenzie ym. 2007) priorisoitiin 82 taudinaiheuttajaa sen mukaan, kuinka merkittävät vaikutukset niillä on luonnonvaraisiin eläimiin, ihmisiin ja tuotantoeläimiin. Vaikutuksiltaan luonnonvaraisiin eläimiin ND arvioitiin seitsemänneksi tärkeimmäksi, tuotantoeläinvaikutuksiltaan tärkeimmäksi ja kokonaisprioriteetiltaan viidenneksi arvioiduista taudinaiheuttajista. ND:n taudinpurkauksia todetaan EU:ssa vuosittain kymmeniä maan rokotuspolitiikasta riippumatta (Kuva 1). Näiden taudinpurkausten yhteydessä on hävitetty satoja tuhansia lintuja vuosien 1997-2007 aikana. Suomessa tautia todettiin viimeksi kalkkunoissa vuonna 2004, jolloin hävitettiin yhden tartunnan saaneen tilan kalkkunat (yli 10 000 lintua). Suomessa ND:tä vastaan rokottaminen on kiellettyä, ja sen leviämisen riskiä hallitaan useilla eri tasoilla, alkaen tiloilla käytännön työssä toteutettavasta tautisuojauksesta.

ND:n kaltaisten vakavien ja helposti leviävien tautien tehokas tautivastustus edellyttää kansainvälistä lähtökohtaa. Maailman kauppajärjestön (WTO) tavoitteena on mahdollistaa vapaan kaupan toteutuminen vaarantamatta kuitenkaan ihmisten, eläinten tai kasvien terveyttä. SPSsopimuksen (WTO 1994) mukaan jäsen ei saa yksipuolisesti rajoittaa kauppaa ilman tieteellistä näyttöä sen aiheuttamasta riskistä. Kansainvälisen eläintautijärjestön (OIE) riskinhallintasuositukset hyväksytään kansainvälisinä standardeina eläintautien leviämisen estämisessä. EU:ssa säädetään sisämarkkinakaupasta ja ND-riskien hallintavaatimuksista (Neuvoston Direktiivi 90/539). Suomen ND:n vastustuksen säännöt ja periaatteet vahvistetaan EU-tasolla (Neuvoston Direktiivi 92/66 ETY), mutta niiden täytäntöönpano tapahtuu kansallisesti (MMM EEOp 3/EEO/96). Suomen siipikarjanlihan tuotannossa sekä elinkeinolla että tuottajillakin on rooli eläintautien riskinhallinnassa. Lintujen ja siitosmunien maahantuontien riskinhallinnan tueksi elinkeino perusti Eläintautien torjuntayhdistyksen (ETT) vuonna 1994. Elinkeino on yhteistyössä Elintarviketurvallisuusviraston (Evira) kanssa laatinut myös siipikarjan terveystarkkailuohjelman, jonka avulla siitoslintupopulaation terveydentilaa seurataan. ND-taudinpurkaus vuonna 2004 havaittiin ohjelman puitteissa. Viime kädessä tuottajalla on vastuu ja mahdollisuus suojata oma tilansa taudeilta sekä laissa säädetty velvollisuus ilmoittaa mm. ND:n oireiden esiintymisestä viranomaisille (Eläintautilaki 1980/55).

Endeemisen tartunnan esiintymisen johdosta markkinahinnat liikkuvat kysynnän ja tarjonnan ohjaamina taudin ilmaantuvuuden mukaan. Tauti ja sen riski sisällytetään tuotantopäätöksiin. Tila voi silti kärsiä taudista enemmän tai vähemmän kuin mitä sille korvautuu markkinoiden tautimarginaalin kautta (Dijkhuizen ym. 1995). ND:n kaltaisissa eksoottisissa taudeissa tällaista säätelyä ei ole. Vaikutukset toimijoihin voidaan yksinkertaisimmillaan jakaa ylimääräisiin kustannuksiin (esim. desinfiointi), menetettyihin tuloihin (esim. myyntitulo), ylimääräisiin tuloihin (esim. hinnannousu) ja vähentyneisiin kustannuksiin (esim. rehuntarve) (Dijkhuizen ym. 1995). Taudinvastustuksen ja - 
purkauksen vaikutusten syntyminen on monimutkainen erilaisten tapahtumasarjojen lopputulos. Kokonaisvaikutusten lisäksi on selvitettävä kustannusten ja hyötyjen kohdentuminen eri toimijoille.

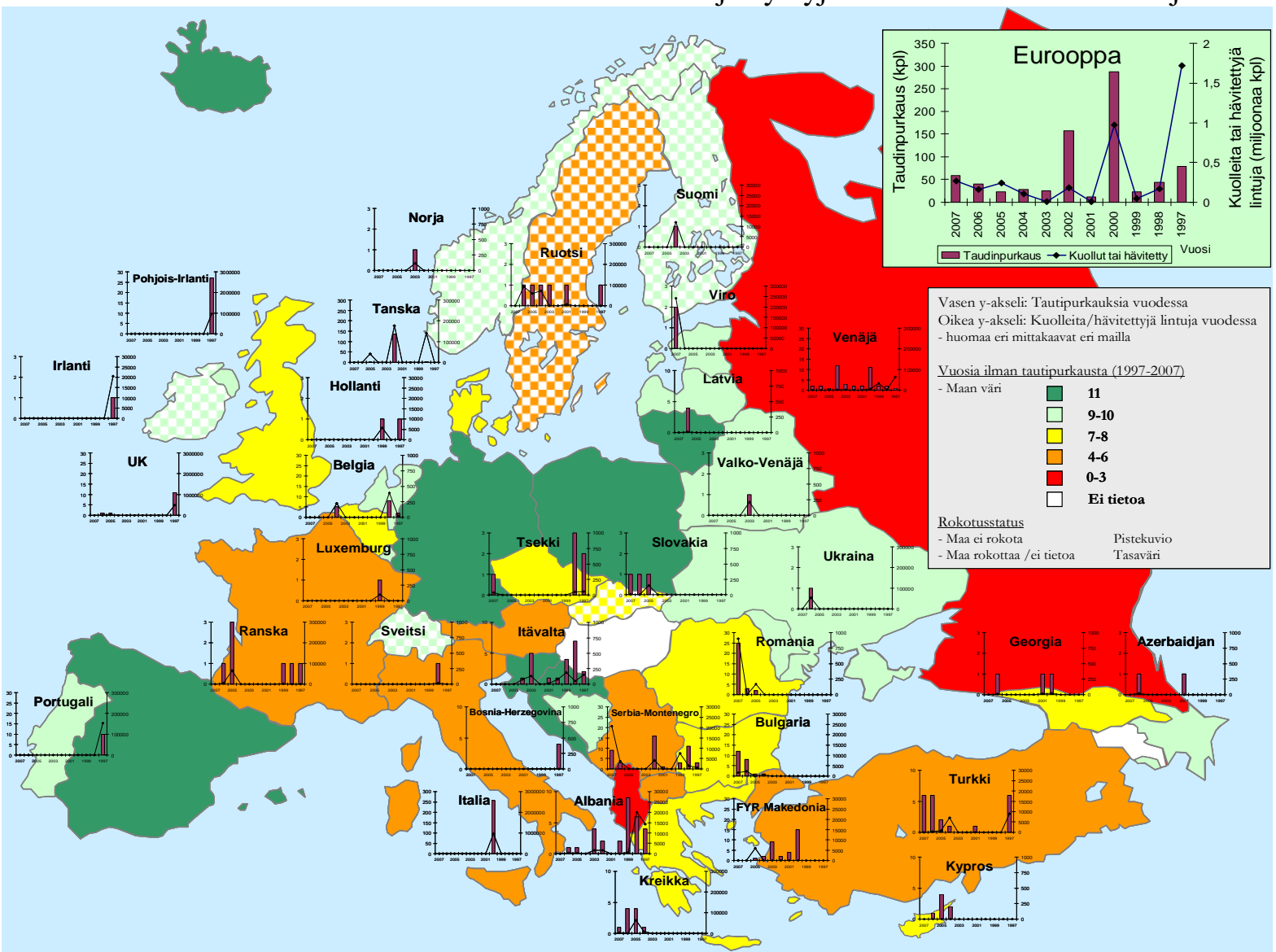

Kuva 1. Raportoidut Newcastlen tautitapaukset Euroopan maissa 1997-2007 sekä riskinhallinnan rokotuskäytännöt.

\section{Newcastlen taudin vaikutusten viitekehys}

Eksoottisten tautien vaikutukset voidaan jakaa neljään eri kategoriaan (Bruemmer 2003). Tautien fyysisiin vaikutuksiin kuuluu niiden vaikutus eläimiin ja sitä kautta ihmisiin. Psykologinen vaikutus kohdistuu ihmisten käsitykseen elintarvikkeista ja niiden tarjonnasta. Heikentynyt elintarviketarjonta saattaa johtaa poliittisten vaikutusten kautta luottamuspulaan viranomaisia ja poliittisia toimijoita kohtaan. Taloudellinen vaikutus syntyy välillisesti muiden vaikutusten seurauksena.

ND:n vaikutusten ja niiden jakautumisen tarkastelemiseksi rakensimme viitekehyksen (Kuva 2), joka auttaa hahmottamaan taudinpurkauksen epidemiologiaa ja taudin seurannan ja riskinhallinnan tapahtumasarjojen seurauksia sekä tautivapaana että tautipurkauksen aikana. Kehyksestä on jätetty huomioimatta ihmisten ja valtioiden pelästymisreaktioiden vaikutukset.

\section{Epidemiologinen tapahtumasarja}

Epidemiologisen tapahtumasarjan aikana (Kuva 2, sarake A) tartunnalle herkkä siipikarjapopulaatio altistuu PMV-1 -virukselle, saa tartunnan ja erittää virusta tartuttaen näin uusia taudille herkkiä lintuja. Taudinpurkauksesta seuraa lintujen sairastuminen ja siten niiden hyvinvoinnin heikkeneminen. Parvissa kuolleisuus lisääntyy, mutta niissä esiintyy myös vastustuskykyisiä yksilöitä. Tartunta leviää sekä tilan sisällä että tilojen välillä suorien ja epäsuorien kontaktien avulla; näin syntyy epidemia. Epidemian laajuuteen vaikuttavat useat eri tekijät, kuten tartunnalle herkän populaation koko sekä populaatiossa esiintyvien kontaktien lukumäärä ja taajuus.

Jos tartunta jää pysyvästi kiertämään populaatioon, taudista tulee endeeminen. Tällöin populaatioon muodostuu tasapaino, jossa osa populaatiosta on tartunnalle herkkiä, osa infektoituneita ja osa immuuneja. Osa linnuista kuolee sairastumisen seurauksena. Endeemisessä kierrossa ovat usein myös mukana luonnonvaraiset linnut, jotka voivat toimia viruksen piilevinä kantajina ja levittäjinä. 
Endeemisessä tilanteessa syntyy epidemioita vain kun vastustuskykyisten yksilöiden määrä on huomattavasti herkkien eläinten määrää pienempi. Rokotusohjelman tavoitteena on saavuttaa yllä kuvatun kaltainen tasapainotilanne, jossa epidemian syntyminen on epätodennäköistä.

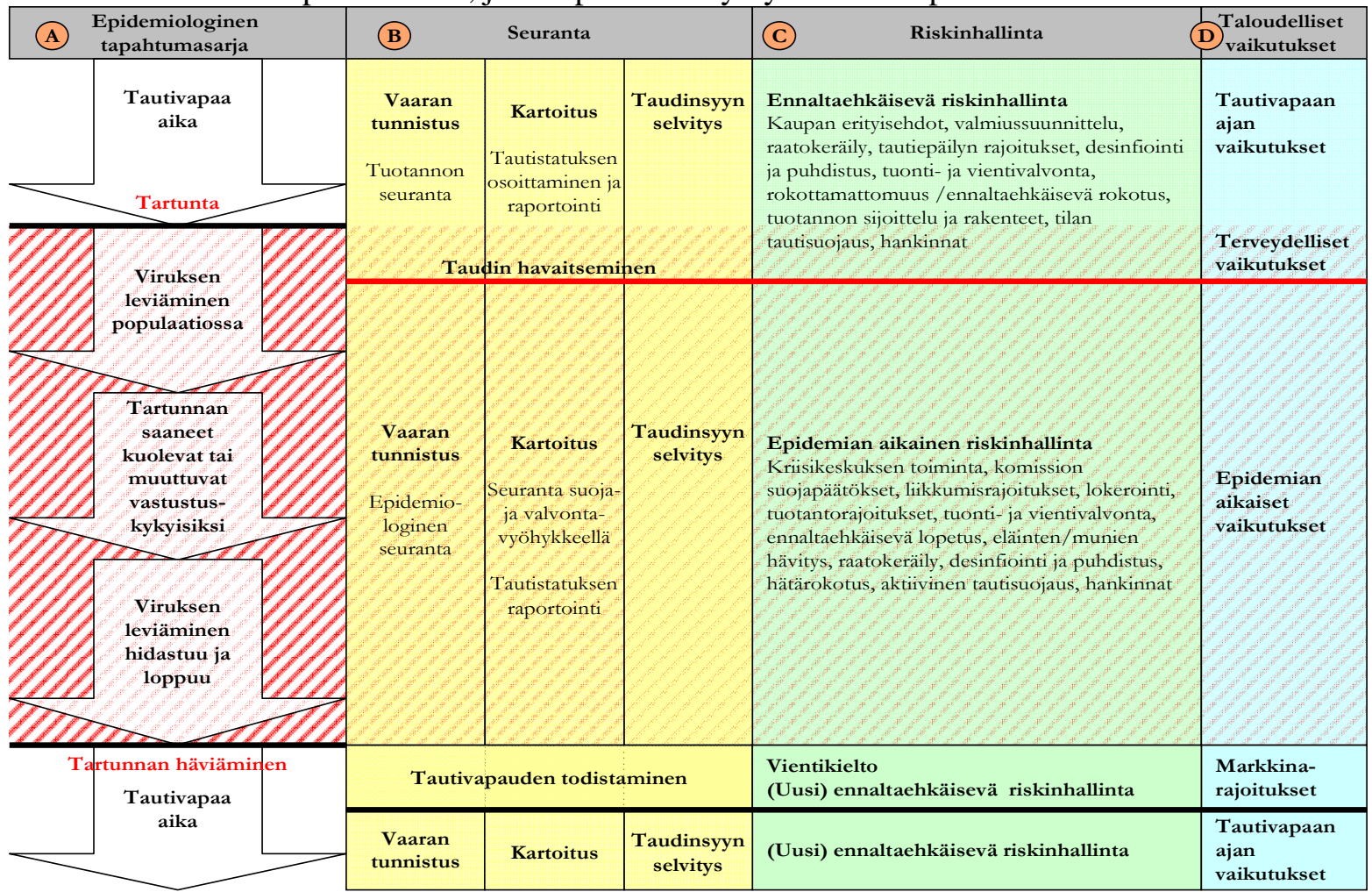

Kuva 2. Viitekehys Newcastlen taudin seurannan ja riskinhallinnan seurauksiin vaikuttavista tekijöistä. (Punaraidallinen tausta viittaa aikaan, jolloin tartunta esiintyy populaatiossa (havaittu tai havaitsematon tartunta)).

\section{Seurannan vaikutukset}

ND:n esiintymistä seurataan jatkuvasti (Kuva 2, sarake B). Suomen rokottamattomuusstatuksen johdosta ND:n esiintymistä seurataan vuosittain siitoslintupopulaatiossa siipikarjan tuotannosta poistettujen siitoslintuparvien tutkimuksissa. Seurannan perusteella voidaan EU:lle ja OIE:lle todentaa Suomen olevan vapaa ND:sta. Edellä kuvatun lisäksi taudin ajantasaista esiintymistä seurataan kliinisten oireiden avulla (lisääntynyt kuolleisuus, muninnanlasku yms.) sekä diagnostisista näytteistä, joita tutkitaan taudinsyyn selvittämiseksi. Positiivinen löydös käynnistää riskinhallintatoimenpiteet. Lisäksi voidaan seurata tekijöitä, jotka mahdollisesti vaikuttavat populaation taudille altistumisen riskiin (mm. muiden maiden tartuntatilanne sekä muutokset tuotantorakenteessa).

Taudinpurkauksen aikana diagnostisten näytteiden määrä tavallisesti lisääntyy. Lisäksi otetaan näytteitä suoja- ja valvontavyöhykkeellä olevilta tiloilta. Taudinpurkauksen aikana tehdään myös tartuntatilojen riskikontaktien selvittelyä ja muuta koko populaatiota koskevaa vaaran tunnistamista.

\section{Riskinhallinnan vaikutukset}

ND:n riskinhallintatoimenpiteillä (Kuva 2, sarake C) pyritään puuttumaan taudin epidemiologiseen tapahtumasarjaan ja siten vähentämään tautiriskiä seuraavin toimin: 1) estetään viruksen leviäminen populaatioon; 2) jos viruksen leviämistä ei pystytä estämään, vähennetään sen esiintymistä populaatiossa ja 3) hävitetään virus populaatiosta ja ympäristöstä. Painotus voi taudinvastustuspolitiikasta riippuen olla taudinpurkausten todennäköisyyden vähentämisessä tai epidemiologisten vaikutusten pienentämisessä. Suomessa vastustuksen painopiste on perinteisesti ollut tartunnan leviämisen ennaltaehkäisyssä sekä viruksen hävittämisessä populaatiosta (esim. tartunnan saaneiden eläinten lopettaminen). Joissakin maissa käytössä olevan ennaltaehkäisevän rokottamisen avulla puolestaan pyritään vähentämään viruksen esiintymistä populaatiossa.

Tautivapaana aikana riskinhallinnan painopisteenä on lintujen virukselle altistumisen estäminen kaikilla tasoilla. Taudinpurkauksen toteamisen jälkeen bioturvallisuutta vahvistetaan viruksen edelleen 
leviämisen estämiseksi. Tähän tähtääviä toimenpiteitä ovat $\mathrm{mm}$. alueelliset markkinarajoitukset sekä eläinten lopettaminen ja hävittäminen joko niiden saatua tartunnan tai ennaltaehkäisevästi.

\section{Taloudelliset vaikutukset ja niiden kohdentuminen}

ND:1lä on taloudellisia vaikutuksia sekä tautivapaana että taudinpurkauksen aikana (Kuva 2, sarake D). Tautivapaana aikana kustannuksia aiheutuu esimerkiksi tautiseurannasta, tilojen bioturvallisuuden ylläpidosta sekä tuontimääräyksistä. Taudinpurkauksen suoriin kustannuksiin voidaan laskea kuuluvan esim. menetetty tuotanto, taudin hallintakustannukset, maksetut korvaukset sekä liikkumarajoituksista aiheutuvat kustannukset. Epäsuoria kustannuksia aiheutuu ulkomaankaupalle sekä muille tuotantosektoreille (Mahul ja Durand 2000).

Taudin vastustamisen ja ennaltaehkäisyn sekä toisaalta taudinpurkauksen kustannukset ja hyödyt kohdistuvat tautitilanteen mukaan eri toimijoille sekä siipikarjasektorilla että sen ulkopuolella. Ajanjaksojen pituus suhteessa toisiinsa vaikuttaa toimijoiden taloudellisen riskin suuruuteen. Usein ei siis riitä pelkkä taudinpurkauksen kokonaisvaikutusten tarkastelu, vaan on selvitettävä miten kustannukset ja hyödyt jakautuvat eri toimijoiden kesken. Esimerkiksi Tanskan vuoden 2002 NDepidemiassa broilerituottajat kokivat itseensä kohdistuvan riskin niin suureksi, että maksoivat myös kananmunatuotantopuolen rokotukset rokotusohjelman alkaessa.

ND:n taudinpurkauksen taloudellisia vaikutuksia on arvioitu muutamien epidemioiden yhteydessä, mutta ne eivät ole kovinkaan systemaattisia eivätkä keskenään vertailukelpoisia. PohjoisIrlannin vuoden 1973 epidemiasta tehdyn arvioinnin perusteella kustannukset jakautuivat hallinnon, tuottajien sekä teollisuuden kesken siten, että hallinto (veronmaksajat) kantoi suurimman osan kustannuksista (Leslie 2000). Suurin hallinnon kuluerä koostui terveistä linnuista maksetuista korvauksista ja toiseksi suurin taudin torjunnasta valvonta-alueella. Varsinaiset kustannukset taudin torjunnasta tautitiloilla jäivät melko pieniksi.

Kuvassa 3 on kuvattu epidemiologisesta tapahtumasarjasta, riskinhallinnasta sekä seurannasta johtuvien taloudellisten seurausten syy-yhteyksiä sekä toimijat, joille ND:sta tai sen torjunnasta aiheutuu kustannuksia tai hyötyjä. Taudinpurkauksen aikana tilat voidaan jakaa tartuntatiloihin, suojatai valvontavyöhykkeillä oleviin, sekä kokonaan taudin suorien vaikutusten ulkopuolella oleviin tiloihin. Tautitiloilla kustannuksia muodostuu mm. hävitettyjen lintujen arvon menettämisestä ja tuotantokatkoksista. Nykyisten säädösten mukaan hävitettyjen lintujen arvo korvataan tuottajille ainakin osittain. Taudinhallintatoimenpiteistä ja kuluttajien käyttäytymisestä johtuvat tarjonta- ja kysyntävaikutukset sekä oma työ ja henkinen kärsimys koskevat kuitenkin kaikkia tuottajia - olipa tila sitten tartuntatila tai ei - ja näistä ei korvauksia juuri makseta.

Tilatasolta tautikustannusvaikutukset välittyvät pahimmillaan koko siipikarjaketjuun. Taaksepäin välittyvät vaikutukset kohdistuvat tuotantopanoksia myyviin yrityksiin. Esimerkiksi siipikarjanrehun kysyntä saattaa laskea tuotantokatkosten takia, millä saattaa olla seurannaisvaikutuksia puolestaan muun eläinrehun tuotantoon. Eteenpäin välittyvät vaikutukset koskevat mahdollisesti koko loppuketjua. Kustannuksia voi kertyä mm. keskeytyksistä ja häiriöistä lintujen saannissa, tehokkuustappioista, tuotantokierron keskeytymisestä, mahdollisista vientirajoituksista sekä kysynnän laskusta. Ketjun loppupään yritykset pystyvät jossain määrin hillitsemään vaikutuksia kylmäsäilytyksellä, jatkojalostuksella tai tuontimääriä sopeuttamalla (Upton 2006).

Epidemian aikaiset rajoitusalueet voivat vaikuttaa elämystuottajiin (matkailu, metsästys) sekä harrastajiin (kyyhkyskilpailut ja koristelintunäyttelyt). Hallinnolle kustannuksia aiheuttavat $\mathrm{mm}$. kriisikeskuksen perustaminen, taudin diagnosointi, torjunta ja hävitys, suoja- ja valvontavyöhykkeen perustaminen, sekä maksetut korvaukset. Valtio saa EU:lta osan tuottajille maksamistaan korvauksista.

Kuluttajiin tautipurkaus voi vaikuttaa joko hyvinvointia lisäävästi tai vähentävästi, riippuen pitkälti siitä, kuinka suuri osa tuotannosta menee vientiin ja kuinka suuri osa viennistä keskeytyy. Vientiorientoituneen maan viennin keskeytyessä kansalliset markkinat täyttyvät ylitarjonnasta painaen hintoja alas kuluttajien eduksi ja tuottajien vahingoksi - edellyttäen että epidemia on tarpeeksi pieni, jottei tarjonta vähene enempää kuin kysyntä (Mangen ja Burrell 2003). Kauppavaikutukset riippuvat mm. taudinaiheuttajasta ja sen zoonoottisesta potentiaalista, tuonnin ja viennin määrästä ja merkityksestä, tautimaan viranomaisten uskottavuudesta sekä kauppakumppaneista (Thiermann 2004). Suomen siipikarjanlihan vienti suhteessa tuotantoon ja tuonti suhteessa kulutukseen ovat varsin alhaisia ja Suomessa tai Suomeen tuovassa maassa esiintyvä tautipurkaus voi olla suhteellisen 
maltillinen kauppavaikutuksiltaan (OECD 2007). Toisaalta on hyvä huomata, että kyseiset luvut ovat moninkertaistuneet viimeisen kymmenen vuoden aikana.

Korvaavien tuotteiden tuottajat ovat taudinpurkauksen potentiaalisia hyötyjï̈. ND-epidemian yhteydessä siipikarjanlihan kysyntä tai tarjonta saattaa laskea ja korvautua muilla eläinperäisillä tuotteilla. Myös raadonkuljetus-, renderöinti- ja desinfektioyrityksillä riittää kysyntää taudinpurkauksen aikana. Tuonnin mahdollinen lisääntyminen hyödyttää tuojia, kuljetusyrityksiä sekä osaa kuluttajista.

Tässä tarkastelussa ei ole huomioitu kuluttajien tai muiden maiden pelästymisreaktiosta mahdollisesti aiheutuvia markkinahäiriöitä. Kuluttajareaktioihin vaikuttavat esimerkiksi taudin zoonoottinen potentiaali, kuluttajien tai kauppakumppanien luottamus viranomaisiin sekä se, miten riskistä viestitään; kysynnän muutos ei välttämättä ole suhteessa todelliseen riskiin vaan mielikuviin. Myös lintujen hyvinvoinnin huonontuminen tai epidemian hallintatoimet (esim. lintujen massahävitykset) voidaan kansalaisen tasolla kokea eettisesti kestämättömiksi.

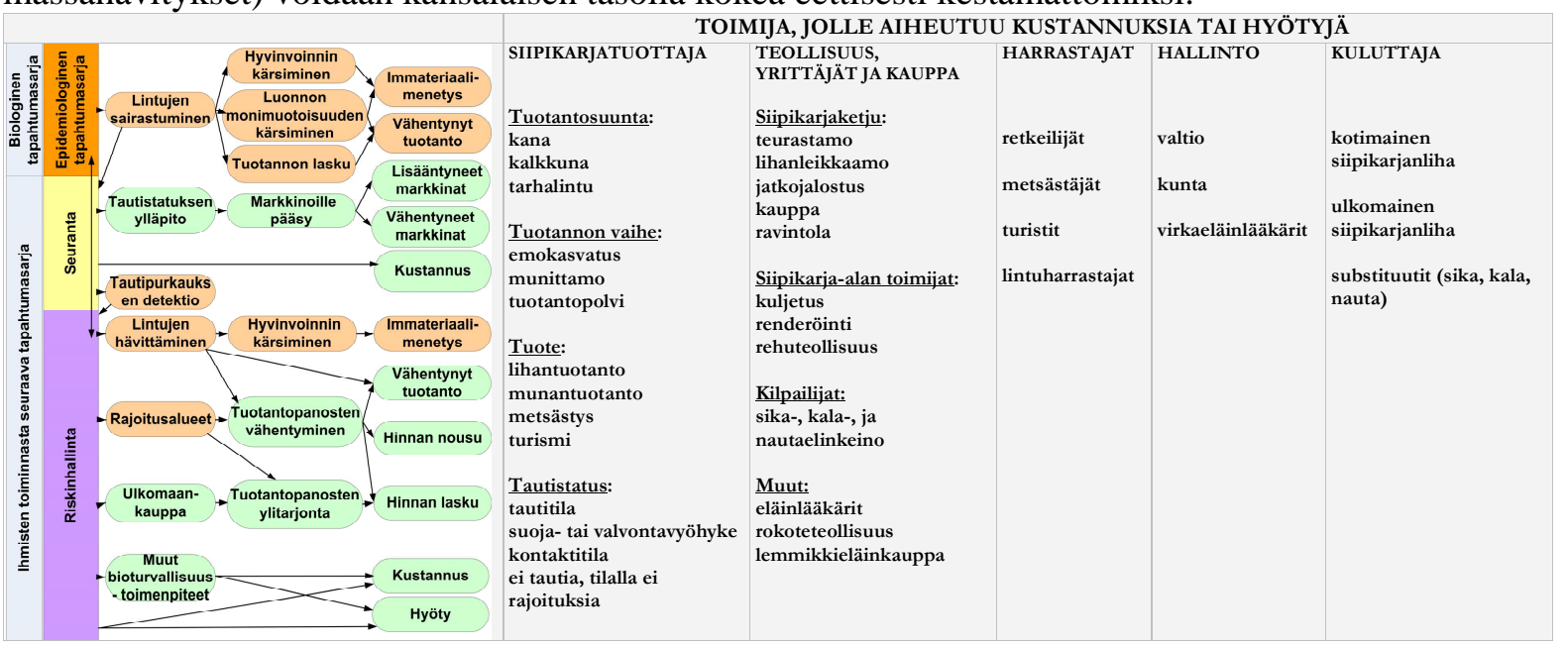

Kuva 3. Taloudellisten vaikutusten synty ja kohdentuminen. Vasemmalla on esitetty epidemiologisen tapahtumasarjan, seurannan ja riskinhallinnan sekä taloudellisten vaikutusten syy-seuraus -suhde. Vihreät vaikutukset syntyvät tautivapaana ja/tai taudinpurkauksen aikana, oranssit vain taudinpurkauksen aikana. Oikealla on esitetty toimijat, joihin bioturvallisuuden ja taudinpurkauksen vaikutukset kohdistuvat Newcastlen tautitapauksessa.

\section{Pohdinta}

ND:n vaikutusten tarkastelemiseksi hahmoteltu viitekehys selkeyttää sekä epidemiologisten että riskinhallintatapahtumasarjojen vaikutusten yhteyksiä ND:n taloudellisiin vaikutuksiin. Kehyksen avulla voidaan selkeyttää sekä tutkia taloudellisten vaikutusten syntymekanismeja, ajankohtaa sekä kohdistumista eri toimijoiden kesken. ND -taudinpurkauksen yhteydessä siipikarjasektoriin kohdistuvalla riskinhallinnalla on Suomessakin vaikutuksia myös siipikarjaelinkeinon sekä maa- ja metsätalousministeriön hallinnonalan ulkopuolelle. Näidenkin vaikutusten taloudellisten seurausten arvioinnissa tulisi huomioida sekä taudin epidemiologinen että riskinhallinnan tapahtumasarja.

Siipikarjatalouden tulevaisuuden näkymät Suomessa ovat epävarmoja. Siipikarjanlihan tuotanto on kasvanut ja tuotantorakenne muuttunut kilpailukyvyn lisäämisen myötä. Samaan aikaan siipikarjanlihan tuonti on lisääntynyt ja tulevaisuuden tukipolitiikkaan liittyy epävarmuuksia. Merkittävää epävarmuutta liittyy myös tautien aiheuttamaan riskiin. Markkinatilanteesta johtuvaan tai poliittiseen päätöksentekoon liittyvään epävarmuuteen on yksittäisen tuottajan vaikea vaikuttaa. Sen sijaan tautien leviämiseen liittyvää epävarmuutta voi myös tuottaja omalta osaltaan hallita.

Bioturvallisuus on julkishyödyke, jota yksityiset markkinat eivät pääsääntöisesti tuota yhteiskunnan kannalta riittävästi. Tästä johtuva valtion mukanaolo tuo esiin joukon valintoja: Miten turvallisuus tuotetaan? Mikä on sopiva määrä? Kuka sen maksaa? Miten sitä valvotaan? EU:ssa on alettu yhä enenevässä määrin pohtia eläintautien kustannusten jakautumista eri toimijoiden kesken osana eläinten terveyteen liittyvien toimien harmonisointia. Yhtenä kimmokkeena tälle pohdinnalle oli se, että vuosien 1997-2005 välillä 85\% EU:n eläinlääkintäbudjetista hupeni kolmen taudin (suu- ja sorkkatauti, BSE ja lintuinfluenssa) hoitamiseen kahdessa maassa (Britannia ja Hollanti). Tautien 
ennaltaehkäisyyn ei näin budjetin voimavaroja juurikaan ollut käytettävissä (European Commission 2007).

Taudin vastustuksesta ja tautipurkauksesta johtuvien kustannusten ja hyötyjen jakautuminen eri toimijoille on riippuvainen sekä taudin riskistä että toimijoiden vaihtoehtoisista strategioista. Usean taudin osalta riskin kantaja ja riskistä hyötyjä eivät ole sama taho. Kustannusten ja hyötyjen kohdistumiseen voidaan kuitenkin vaikuttaa erilaisilla poliittisilla ja elinkeinon sisäisillä ratkaisuilla, esimerkiksi erilaisilla tuilla, korvauksilla, vakuutuksilla, rahastoilla, jne. EU:n eläinterveyspolitiikan arvioinnin yhteydessä toteutettiin alustava tutkimus erilaisista kustannusten jakomenetelmistä, koska nykyisten menetelmien todettiin olevan hyvin kirjavia. Yhteisönlaajuisesti harmonisoidut bioturvallisuuskustannusten jakomenetelmät nähdään arvioinnissa toteutettavissa olevana vaihtoehtona. Näiden käyttöönoton vaikutusta suomalaisen siipikarjanlihan tuotantoketjun kilpailukykyyn tulisikin tarkastella huomioiden Suomen tuotantorakenteeseen, riskinhallintaan sekä tautiriskeihin liittyvät erityispiirteet.

Kirjallisuudessa kuvatut analyysit ND -taudinpurkausten taloudellisista vaikutuksista eivät ole kovinkaan läpinäkyviä koskien analyysiin sisällytettyjä tekijöitä. Tästä syystä niitä on vaikea verrata toisiinsa, eikä tuloksia myöskään voida suoraan hyödyntää muissa maissa, koska mm. tuotantorakenteet ovat eri maissa hyvin erilaisia. Tehdyistä analyyseistä saa kuitenkin käsityksen taudinpurkausten taloudellisten vaikutusten suuruusluokasta. Taudinpurkauksen taloudellinen vaikutus on tiiviisti yhteydessä purkauksen laajuuteen sekä kestoon. Vaikutusten arvioimiseksi tarvitaan siksi myös arvio taudin leviämisen ja populaation altistumisen riskistä. Tällaisen analyysin avulla voitaisiin arvottaa myös ND:n merkitystä suhteessa muihin siipikarjaketjun vaaroihin, priorisoida riskinhallintastrategioita, sekä arvioida niiden kustannustehokkuutta (esim. kannattaako rokottaa vai ei). Lisäksi analyysia voitaisiin hyödyntää tehtäessä valmiussuunnittelua taudinpurkauksen varalta sekä arvioitaessa tautiriskiä erilaisten tuotantoon kohdistuvien muutosten valossa.

\section{Kirjallisuus}

Bruemmer, B. 2003. Food biosecurity. Journal of the American Dietetic Association 103 (6): 687-691.

Dijkhuizen, A.A., Huirne, R.B.M. \& Jalvingh, A.W. 1995. Economic analysis of animal diseases and their control. Preventive Veterinary Medicine 25: 135-149.

Eläintautilaki 18.1. 1980/55

European Commission. 2006. Evaluation of the Community Animal Health Policy (CAHP) 1995-2004 and alternatives for the future. http://ec.europa.eu/food/animal/diseases/strategy/main_report_part1_en.pdf, avattu $11 / 2007$.

MMM EEOp 3/EEO/96. Maa- ja metsätalousministeriön pääös Newcastlen taudin ja lintuinfluenssan vastustamisesta

Leslie, J. 2000. Newcastle disease: outbreak losses and control policy costs. The Veterinary Record 146: 603606.

Mahul, O. \& Durand, B. 2000. Simulated economic consequences of foot-and-mouth disease epidemics and their public control in France. Preventive Veterinary Medicine 47: 23-38.

Mangen, M.-J.J. \& Burrell, A.M. 2003. Who gains, who loses? Welfare effects of classical swine fever epidemics in the Netherlands. European Review of Agricultural Economics 30 (2): 125-154.

McKenzie, J., Simpson, H. \& Langstaff, I. 2007. Development of methodology to prioritise wildlife pathogens for surveillance. Preventive Veterinary Medicine 81 (1-3): 194-210.

Neuvoston direktiivi 90/539/ETY, annettu 15 päivänä lokakuuta 1990, eläinten terveyttä koskevista vaatimuksista yhteisön sisäisessä siipikarjan ja siitosmunien kaupassa ja tuonnissa kolmansista maista. EYVL L 303, 31.10.1990, s. 6-28.

Neuvoston direktiivi 92/66/ETY, annettu 14 päivänä heinäkuuta 1992, yhteisön toimenpiteistä Newcastlen taudin torjumiseksi. EYVL N:o L 260, 5.9.1992, s.1

OECD. 2007. Impact of animal disease outbreaks and alternative control practices on agricultural markets and trade. Background paper and literature review. TAD/CA/APM/WP(2007)12/FINAL. Paris.

Thiermann, A. 2004. Emerging diseases and implications for global trade. Office International des Épizootics (OIE) Scientific and Technical Review 23 (2): 701-708.

Upton, M. 2006. Market and trade impacts of highly pathogenic avian influenza. Presentation at FAO symposium on Market and Trade Dimensions of Avian Influenza Prevention and Control, Rome, 14 November 2006.

WTO (World Trade Organization). 1994. Agreement on the Application of Sanitary and Phytosanitary Measures. http://www.wto.org/english/docs_e/legal_e/15-sps.pdf, avattu 11/2007. 